\title{
Phytofabrication of Iron Nanoparticles for Hexavalent Chromium Remediation
}

\author{
Adam Truskewycz, ${ }^{*},+$, Ravi Shukla, ${ }^{\ddagger}$ and Andrew S. Ball ${ }^{\dagger}$ \\ ${ }^{\dagger}$ Centre for Environmental Sustainability and Remediation, School of Science, RMIT University, GPO Box 71, Bundoora, Victoria \\ 3083, Australia \\ ${ }^{\ddagger}$ Nanobiotechnology Research Laboratory and Centre for Advanced Materials \& Industrial Chemistry, School of Science, RMIT \\ University, GPO Box 2476, Melbourne, Victoria 3000, Australia
}

\section{Supporting Information}

\begin{abstract}
Hexavalent chromium is a genotoxic and carcinogenic byproduct of a number of industrial processes, which is discharged into the environment in excessive and toxic concentrations worldwide. In this paper, the synthesis of green iron oxide nanoparticles using extracts of four novel plant species [Pittosporum undulatum, Melia azedarach, Schinus molle, and Syzygium paniculatum (var. australe)] using a "bottom-up approach" has been implemented for hexavalent chromium remediation. Nanoparticle characterizations show that different plant extracts lead to the formation of nanoparticles with different sizes, agglomeration tendencies, and shapes but similar amorphous nature and

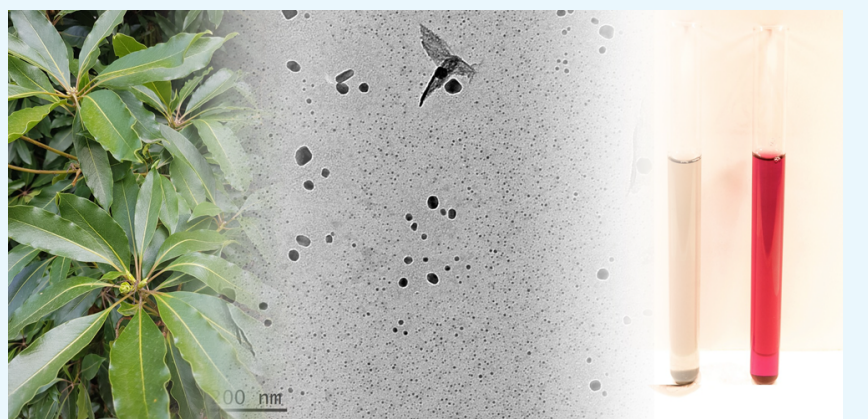
elemental makeup. Hexavalent chromium removal is linked with the particle size and monodispersity. Nanoparticles with sizes between 5 and $15 \mathrm{~nm}$ from M. azedarach and P. undulatum showed enhanced chromium removal capacities (84.1-96.2\%, respectively) when compared to the agglomerated particles of $S$. molle and S. paniculatum with sizes between 30 and $100 \mathrm{~nm}$ (43.7-58.7\%, respectively) in over 9 h. This study has shown that the reduction of iron salts with plant extracts is unlikely to generate vast quantities of stable zero valent iron nanoparticles but rather favor the formation of iron oxide nanoparticles. In addition, plant extracts with higher antioxidant concentrations may not produce nanoparticles with morphologies optimal for pollutant remediation.
\end{abstract}

\section{INTRODUCTION}

Chromium is a valuable resource in a number of different industries, having essential roles in refractories, alloys, electroplating, pigments, catalyst generation, and leather tanning, to name a few applications. It is most commonly found in the environment as the trivalent (Cr III) cation $\mathrm{Cr}^{3+}$ or the hexavalent ( $\mathrm{Cr} \mathrm{VI}$ ) oxyanion, that is, $\mathrm{HCrO}_{4}^{-}$and $\mathrm{CrO}_{4}{ }^{2-2}$. Trivalent chromium is an essential macronutrient, which aids in the regulation of lipid, carbohydrate, and protein metabolism; however, overabundance may lead to erythrocyte membrane disturbances and cause skin irritation. ${ }^{3}$ Hexavalent chromium is considerably more toxic than its trivalent counterpart. ${ }^{4}$ Unlike $\mathrm{Cr}(\mathrm{III})$, it can penetrate the skin and kill cells and/or damage DNA through the generation of reactive oxygen species. It is genotoxic and recognized as a human carcinogen (group 1) by the World Health Organization. In addition, $\mathrm{Cr}(\mathrm{VI})$ is considerably mobile in soils and waterways, increasing its potential for human and widespread ecosystem exposure.

More than 1760 industrial facilities have been listed by the USEPA's “Toxic Release Inventory-2003" for releasing chromium into the environment with a total discharge of approximately 52600 metric tons. $^{6}$ For example, in India, it is estimated that greater than 2000 tons of chromium is released into the environment annually. Wastewater from some of these regions contains up to $5000 \mathrm{ppm}$ of chromium, far exceeding the discharge limit of 2 ppm.

As a consequence of the amounts of $\mathrm{Cr}$ being released into the environment and the potential environmental impact, a number of different techniques have been implemented for the removal of $\mathrm{Cr}(\mathrm{VI})$ species from the environment. The environmental remediation of chromium is faced with a plethora of different factors and conditions, which must be considered, that is, $\mathrm{pH}, \mathrm{Cr}(\mathrm{VI})$ concentration, temperature, interfering species in aqueous environments, absence of oxygen in groundwater, likelihood of contamination to pose a health risk, time-sensitive remediation occurrences, and so forth. Considering this, different remediation technologies may be required in different situations. The benefits and disadvantages of each technology are compared in Table 1.

Recently, the use of nanoparticles for the remediation of hexavalent chromium species has been investigated. Zhou et

Received: March 5, 2018

Accepted: August 7, 2018

Published: September 7, 2018 
Table 1. Current Hexavalent Chromium Removal Strategies ${ }^{a}$

\begin{tabular}{|c|c|c|c|}
\hline technique & approach & advantages & disadvantages \\
\hline adsorption & activated carbon & $\begin{array}{l}\text { high absorption capacity, can remove both } \mathrm{Cr}(\mathrm{VI}) \text { and } \\
\mathrm{Cr}(\mathrm{III}) \text { species }\end{array}$ & $\begin{array}{l}\text { expensive, nonselective, complexing agents often needed for } \\
\text { optimal performance }\end{array}$ \\
\hline \multirow[t]{2}{*}{ filtration } & $\begin{array}{l}\text { polymetric } \\
\text { membranes }\end{array}$ & low space requirements & $\begin{array}{l}\text { extreme chemical and thermal environments may } \\
\text { compromise stability, membrane fowling }\end{array}$ \\
\hline & liquid membranes & high level of selectivity & costly and requires regular monitoring/maintenance \\
\hline $\begin{array}{l}\text { membrane } \\
\text { technology }\end{array}$ & reverse osmosis & can remove both $\mathrm{Cr}(\mathrm{VI})$ and $\mathrm{Cr}(\mathrm{III})$ species & $\begin{array}{l}\text { high initial investment and operational costs, membrane } \\
\text { fouling, disposal of salts }\end{array}$ \\
\hline ion-exchange & $\begin{array}{l}\text { anions resin to } \\
\text { remove } \mathrm{Cr}(\mathrm{VI})\end{array}$ & $\begin{array}{l}\text { requires little maintenance, very effective, suitable for } \\
\text { large- or small-scale applications }\end{array}$ & $\begin{array}{l}\text { pretreatment necessary, removal efficiency is affected by } \\
\text { other water-soluble ions, fouling }\end{array}$ \\
\hline
\end{tabular}

Table 2. Plant Extracts with Their Corresponding Phytochemical Profiles ${ }^{a}$

\begin{tabular}{|c|c|c|c|c|c|}
\hline \multirow[b]{2}{*}{ plant extract } & \multicolumn{5}{|c|}{ phytochemical test } \\
\hline & $\begin{array}{c}\text { reducing powers } \\
{[\mathrm{mg} \text { AA (equiv) } / \mathrm{g}]}\end{array}$ & {$\left[\begin{array}{c}\text { antioxidants } \\
{[\mathrm{mM} \text { Trolox (equiv)/g] }}\end{array}\right.$} & $\begin{array}{c}\text { phenolics } \\
{[\mathrm{mg} \mathrm{GA}(\text { equiv)/g] }}\end{array}$ & $\begin{array}{c}\text { reducing sugars } \\
{[\mathrm{mg} \text { glucose }(\text { equiv }) / \mathrm{g}]}\end{array}$ & $\begin{array}{l}\text { iron-chelating capacity } \\
{[\mathrm{mg} \text { EDTA (equiv)/g] }}\end{array}$ \\
\hline P. undulatum & $5.6^{\mathrm{a}, \mathrm{b}} \pm 0.2$ & $12.6^{\mathrm{a}} \pm 0.4$ & $1.9^{\mathrm{a}} \pm 0.2$ & $42.9^{a} \pm 9.9$ & $2.6^{\mathrm{a}} \pm 0.2$ \\
\hline M. azedarach & $6.0^{\mathrm{b}} \pm 0.1$ & $9.9^{\mathrm{a}} \pm 0.9$ & $1.9^{\mathrm{a}} \pm 0.4$ & $90.9^{b} \pm 16.4$ & $2.1^{\mathrm{a}} \pm 0.3$ \\
\hline S. molle & $4.7^{\mathrm{a}} \pm 0.5$ & $7.2^{\mathrm{a}} \pm 0.5$ & $2.3^{\mathrm{a}} \pm 0.1$ & $64.3^{\mathrm{a}, \mathrm{b}} \pm 7.0$ & $5.8^{\mathrm{b}} \pm 0.5$ \\
\hline $\begin{array}{l}\text { S. } \\
\text { paniculatum }\end{array}$ & $7.5^{c} \pm 0.2$ & $48.1^{b} \pm 5.3$ & $4.0^{b} \pm 0.4$ & $158.4^{\mathrm{c}} \pm 14.5$ & $0.3^{c} \pm 0.0$ \\
\hline
\end{tabular}

${ }^{a}$ Different superscript letters ( $a, b$, and c) denote significant differences between samples.

al. ${ }^{10}$ used $\mathrm{Fe} / \mathrm{Ni}$ bimetallic particles to remove $\mathrm{Cr}(\mathrm{VI})$ from aqueous solution in an ultrasound-assisted system across $\mathrm{pH}$ 3-9; Albadarin et al. ${ }^{11}$ used hydrous cerium oxide nanoparticles for $\mathrm{Cr}(\mathrm{VI})$ adsorption at $\mathrm{pH} 2$; and Valle et al. ${ }^{12}$ showed $\mathrm{Cr}(\mathrm{VI})$ physisorption to $\mathrm{K}_{2} \mathrm{Mn}_{4} \mathrm{O}_{9}$ nanoparticles at $\mathrm{pH}$ 2.

Generating iron nanoparticles through the reduction of iron salt precursors with various crude plant extracts has been widely demonstrated and has been hailed for its environmentally friendly nature and relatively low cost when compared to alternative methods. However, the reproducibility of results in terms of nanoparticle properties (i.e., size, shape, reactivity, monodispersity, oxidation potential, crystallinity, etc.) presents a challenge. Many different bioactive molecules found within plant cells (e.g., polyphenols, proteins, reducing sugars, and lipids) are likely to interact with iron precursors to influence nanoparticle formation and properties. The application of iron and bimetallic nanoparticles is vast; however, their use in the environmental remediation of organic and inorganic pollutants has shown encouraging results.

Wang et al. ${ }^{13}$ synthesized iron nanoparticles with green tea and eucalyptus leaves, which were able to remove 59.7 and $41.4 \%$ of nitrate, respectively, from an initial concentration of $20 \mathrm{mg} / \mathrm{L}$. Luo et al. $^{14}$ showed that grape leaf-mediated synthesis of $\mathrm{Fe} / \mathrm{Pd}$ bimetallic nanoparticles removed $81.7 \%$ of orange II dye from solution with an initial concentration of 50 $\mathrm{mg} / \mathrm{L}$ in over $12 \mathrm{~h}$. Martínez-Cabanas et al. ${ }^{15}$ used eucalyptusgenerated $\mathrm{Fe}$ nanoparticles encapsulated in a chitosan matrix for the removal of $\mathrm{As}(\mathrm{V})$ using column flow-through experiments, reporting that almost $100 \%$ of $\mathrm{As}(\mathrm{V})$ from a $100 \mu \mathrm{g} / \mathrm{L}^{-}$solution was captured or transformed in over $30 \mathrm{~h}$ at a flow rate of $2 \mathrm{~mL} / \mathrm{min}^{-1}$.

Current studies utilizing plant extracts for the synthesis of iron nanoparticles tend to select plant candidates based on high antioxidant concentrations; ${ }^{15,16}$ however, this may not be beneficial for optimal iron nanoparticle morphologies as iron is highly reactive and is likely to interact with various phytochemicals in plant extracts in different manners. To test this, plants were selected based on their differing antioxidant profiles and interesting phytochemical makeup, all of which have been linked to antimicrobial and/or medical applications. ${ }^{17-20}$

The aim of this study was to obtain water-soluble phytochemical extracts from the leaves of four different plant species found within Australia [Pittosporum undulatum, Melia azedarach, Schinus molle, and Syzygium paniculatum (var. australe)] and use these extracts to reduce iron salt precursors into iron nanoparticles. All plant species used in this study are novel in terms of iron nanoparticle synthesis and have diverse and varying phytochemical profiles. Furthermore, their use for antimicrobials and therapeutics indicate that they have interesting phytochemical compositions, which may lead to novel interactions between biological and inorganic species. $^{21-24}$ The differences in nanoparticle morphologies and physiochemical properties, along with their capacity to remove $\mathrm{Cr}$ (VI) species from solution, were investigated.

\section{RESULTS AND DISCUSSION}

Characterization of Plant Extracts. In the search for plant species capable of generating "green" nanoparticles with optimal morphologies/properties, much of the selection process has focused on species containing high plant antioxidant concentrations. Although increasing antioxidant concentrations are often trended with increasing reducing powers, their ability to instill optimum morphological nanoparticle features has not been ascertained. From our results, the antioxidant concentrations for $P$. undulatum, $M$. azedarach, S. molle, and S. paniculatum were 12.6, 9.9, 7.2, and $48.1 \mathrm{mM}$ Trolox (equiv) $/ \mathrm{g}$, respectively, with only $S$. paniculatum showing statistically higher concentration. Reducing powers of the same plant extracts were 5.6, 6.0, 4.7, and $7.5 \mathrm{mg}$ ascorbic acid (AA) (equiv)/g, respectively, indicating that the species with the highest and lowest antioxidant concentrations also possessed the highest and lowest reducing powers (Table 2). Antioxidative effects have been linked with the generation of reductones, which are free radical chain 
reaction terminators. Therefore, antioxidant activity has, in some cases, a relationship with the reductive capacity. ${ }^{25}$ Phenols are known antioxidants, and therefore, it is no surprise that phenolic content followed the same trend as antioxidant concentration. P. undulatum, M. azedarach, S. molle, and S. paniculatum possessed phenolic concentrations of 1.9, 1.9, 2.3, and $4.0 \mathrm{mg}$ gallic acid (GA) (equiv)/g with only S. paniculatum showing statistically higher concentration (Table 2 ).

Reducing sugars, as their name suggests are reducing agents with the capacity to transform iron salts to nanoparticles. ${ }^{26} P$. undulatum and $S$. mollepossessed the lowest reducing sugar concentrations (42.9 and $64.3 \mathrm{mg}$ glucose (equiv)/g, respectively) and were not significantly different from one another. M. azedarach possessed significantly higher reducing sugars than $P$. undulatum but was not statistically different from S. molle. S. paniculatum possessed considerably higher concentrations of reducing sugars than all other plant extracts with $158.4 \mathrm{mg}$ glucose (equiv)/g [ $>1.5$ times that of $M$. azedarach, which contained $90.9 \mathrm{mg}$ glucose (equiv)/g]. It is interesting to note that although $S$. paniculatum contained higher reducing sugar and antioxidant concentrations when compared to the other species, its reducing powers was not significantly greater than those of $P$. undulatum and $M$. azedarach (Table 2).

Iron chelation relates to the ability of plant extract constituents to bind to iron ions and form complex ring structures called chelates. Low and high $\mathrm{pH}$ compromise the stability of the chelating agents. ${ }^{27}$ Although the formation of nanoparticles resulted in highly acidic solutions following mixing of precursors, the original $\mathrm{pH}$ of the plant extract may also alter the chelation capacity. The $\mathrm{pH}$ of plant extracts of $P$. undulatum, M. azedarach, S. molle, and S. paniculatum were $5.95,5.11,6.10$, and 3.87 , respectively (Table 2 ). The ironchelating capacity for the aforementioned plant extracts was 2.6, 2.1, 5.8, and $0.3 \mathrm{mg}$ ethylenediaminetetraaceticacid (EDTA) (equiv)/g, which shows a $\mathrm{pH}$-dependent trend, with lower $\mathrm{pH}$ resulting in lower chelation capacity. SatuéGracia et al. ${ }^{28}$ showed that the anthocyanin antioxidants, delphinidin and malvidin, were unable to bind to copper ions under acidic conditions. S. paniculatum contains the glycosidases of malvidin and delphinidin (i.e., malvidin and delpinidin 3,5-diglucoside), ${ }^{29}$ and its extract is also acidic, and this may explain its low metal chelation capacity. In addition, the type of phytochemicals present within the plant extract may react differently to $\mathrm{pH}$ or other competing influences. Interestingly, S. molle possessed the lowest antioxidant concentration but more than twice the ironchelating capacity of any other extract. Freeze-dried samples of this extract yielded a saplike substance, which may not possess high antioxidative properties but may still bind to the particles. S. molle was the only sample to possess a sap/resin following the lyophilization process.

Synthesis of Iron Nanoparticles. The introduction of iron chloride solution to the plant extract resulted in a color change from a yellow/brown extract to a jet-black nanoparticle solution instantaneously. This indicated that iron nanoparticles had been formed. The $\mathrm{pH}$ of the nanoparticle solutions dropped to 1.5 in all cases; however, nanoparticles were separated from their solution with the aid of dialysis centrifuge tubes [molecular-weight cutoff $30000 \mathrm{Da}$ ] and freeze-dried prior to being used in $\mathrm{Cr}(\mathrm{VI})$ removal studies. The nanoparticles were not magnetic and did not settle out of solution under atmospheric conditions.
Current studies on plant extracts for the synthesis of nanoparticles tend to select plant candidates based on high antioxidant concentrations; ${ }^{30-32}$ however, this may not be beneficial for optimal nanoparticle morphologies. In the current study, antioxidant concentrations along with phenolic content and reducing power capacity have shown little to no statistical differences between P. undulatum, S. molle, and $M$. azedarach. However, the morphologies of the nanoparticle are markedly different (Figure 1). P. undulatum showed a mixed

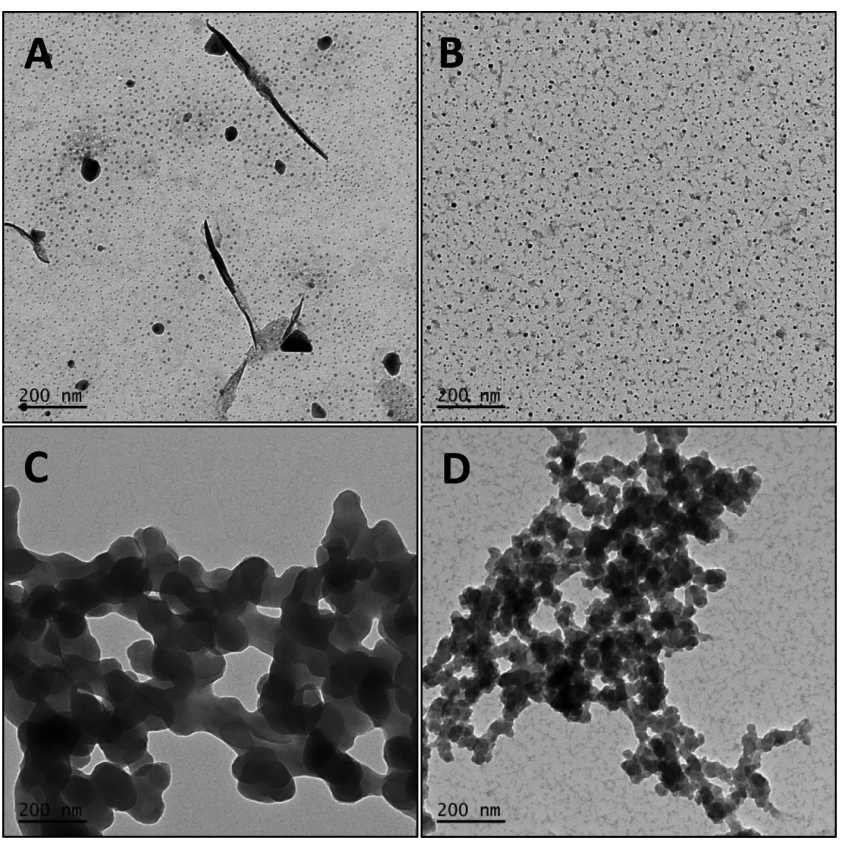

Figure 1. TEM images of iron nanoparticles generated from the reaction between plant extracts and iron chloride precursors. (A) $P$. undulatum NP, (B) M. azedarach NP, (C) S. molle NP, and (D) S. paniculatum NP.

nanoparticle morphology with the majority of particles between 5 and $10 \mathrm{~nm}$ in size. However, a few larger particles with size ranges between 20 and $70 \mathrm{~nm}$ are infrequently present (Figure 1). In addition, there are flat plates that fold into rods with nanometer dimensions. The presence of numerous phytoactive compounds acting on the iron chloride precursor in different ways may be responsible for the numerous different nanoparticle morphologies present. $M$. azaderach possessed particles between 5 and $15 \mathrm{~nm}$ in size with little variation in the nanoparticle morphology. S. molle formed chainlike structures with particles often falling outside of the nanoparticle size range ( $>100 \mathrm{~nm}$ in all particle dimensions). Nanoparticle structures generated from S. paniculatum were ${ }^{33}$ also chainlike in appearance. However, particle sizes were considerably smaller than that of $S$. molle (sizes ranging between 30 and $60 \mathrm{~nm}$ ) (Figures 1 and S1).

If the generation of maximum nanoparticle concentration is the only parameter of interest, then high antioxidant concentration and reducing powers may be beneficial. However, if specific nanoparticle properties are required, high antioxidant concentration may not be a major contributing factor in achieving this. Optimal nanoparticle properties for pollution remediation include particles that are small, monodisperse, possess no particle-particle attraction, and do not passivate readily under aerobic and aqueous conditions. ${ }^{33}$ Our findings, along with other studies that utilize 

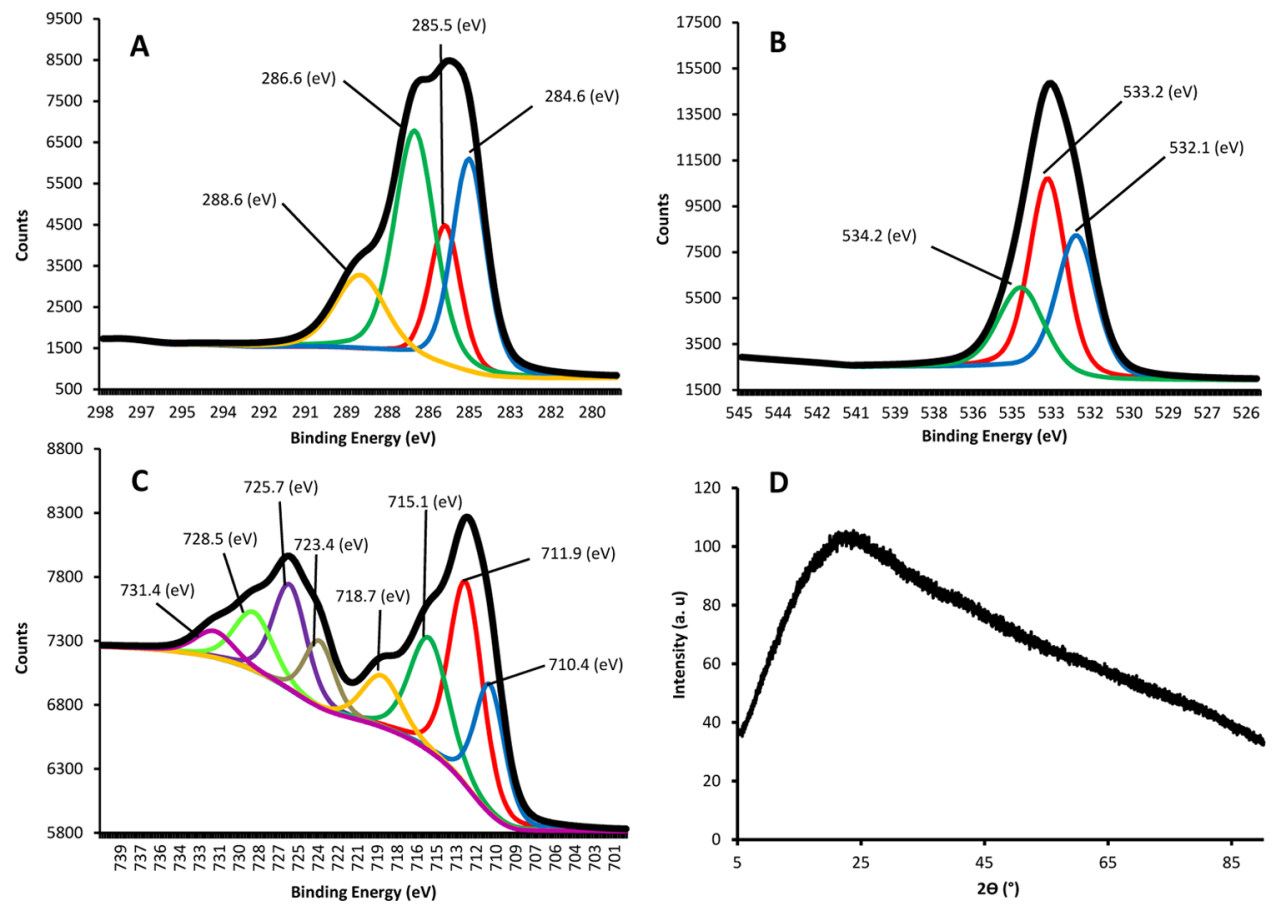

Figure 2. Representative XPS and XRD fingerprints of green nanoparticles (from S. paniculatum). (A) Carbon XPS C1 core level, (B) oxygen XPS O1 core level, (C) iron XPS Fe $2 \mathrm{p}$ core level, and (D) XRD spectra $\left(2 \theta^{\circ}\right)$.

antioxidant rich green tea extracts to generate iron nanoparticles, have shown that high antioxidant concentrations lead to particles that agglomerate and form chainlike structures, $^{34-38}$ thereby reducing the nanoparticle surface area available for remediative interactions.

X-ray Photoelectron Spectroscopy (XPS) and Powder $\mathrm{X}$-ray Diffraction (XRD). There is a common misconception that the production of black iron nanoparticles upon reaction of plant extracts with iron salt precursors confirms the presence of $n \mathrm{ZVI}\left(\mathrm{Fe}^{0}\right) .{ }^{39}$ Reactive iron is likely to interact with active phytochemicals within plant extracts making it difficult to form repeating lattice structures required for crystallinity. This is supported by the amorphous nature of nanoparticles generated in this study and several other studies producing iron nanoparticles with plant extracts. ${ }^{37,39-41}$ In addition to crystallinity, $\mathrm{Fe}^{0}$ nanoparticles are ferromagnetic in nature ${ }^{42}$ and show a representative XPS peak at $706 \mathrm{eV}$ (Figure 2). ${ }^{43,44}$

XPS analysis of freshly synthesized iron nanoparticles with plant extracts and the $\mathrm{C} 1 \mathrm{~s}, \mathrm{O} 1 \mathrm{~s}$, and $\mathrm{Fe} 2 \mathrm{p}$ core levels revealed that the surface of the particles were composed of a mixture of carbon, oxygen, and iron species (Figure 2). Carbon peaks for the representative sample showed peaks at 284.6, 285.5, 286.6, and $288.6 \mathrm{eV}$ corresponding to $\mathrm{C}=\mathrm{C}, \mathrm{C}-\mathrm{O}, \mathrm{C}-$ $\mathrm{OH}$, and $\mathrm{O}-\mathrm{C}=\mathrm{O}$ bonds, respectively. ${ }^{45-48}$ These bonds show that plant bioactive compounds are bound to the surface of the iron oxide nanoparticles. Oxygen was also present on the surface of the particles, with peaks 532.1, 533.2, and 534.2 relating to oxygen in oxyhydroxides, $\mathrm{O}-\mathrm{C}=\mathrm{O}$, and $\mathrm{C}-\mathrm{OH}$ / $\mathrm{O}-\mathrm{N}$, respectively ${ }^{49-52}$ (Figure 2 ). Iron signature peaks were numerous and, indicating the presence of mixed iron oxide species. However, no $\mathrm{Fe}^{0}$ was identified. The peaks identified around 710.4 and 711.9 relate to $\mathrm{Fe}^{3+}$ species representative of ferric compounds such as $\mathrm{Fe}_{2} \mathrm{O}_{3}, \mathrm{Fe}_{3} \mathrm{O}_{4}$, and $\mathrm{FeOOH} .{ }^{53}$ Peaks at $715.1,728.5$, and 718.7 are representative of $\mathrm{Fe}_{2} \mathrm{O}_{3}$; 54,55 however the peak at 711.9 together with $\mathrm{OH}$ groups (peaks at
534.2 and $286.6 \mathrm{eV}$ ) point toward the presence of hydrous iron oxides, such as $\mathrm{FeOOH}$ and/or $\mathrm{Fe}(\mathrm{OH})_{3} \cdot{ }^{56}$

Fourier Transform Infrared (FTIR) Spectroscopy. $S$. paniculatum showed strong representative carboxylic acid signature peaks with $\mathrm{O}-\mathrm{H}$ stretching bonds between 3200 and $3400 \mathrm{~cm}^{-1}$ and $\mathrm{C}=\mathrm{O}$ bonds located between 1725 and $1710 \mathrm{~cm}^{-1}$. P. undulatum also possessed these peaks, but its representation in the spectra was weak (Figure 3). S. molle and

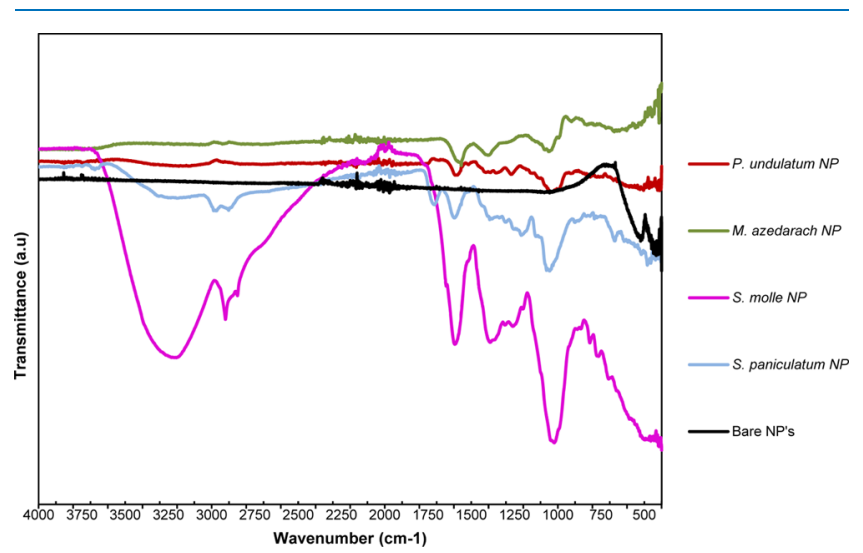

Figure 3. FTIR spectra of iron nanoparticles generated with different plant extracts.

S. paniculatum also showed the existence of phenolic compounds by the presence of $\mathrm{O}-\mathrm{H}$ stretching bonds between 3200 and $3400 \mathrm{~cm}^{-1}, \mathrm{C}-\mathrm{H}$ stretch between 3000 and 2850 $\mathrm{cm}^{-1}$, and $\mathrm{C}-\mathrm{O}$ stretching bonds between 1000 and 1100 $\mathrm{cm}^{-1} .57-59$ Peaks located above $3000 \mathrm{~cm}^{-1}$ are unsaturated and are willing to take part in hydrogen bonding. ${ }^{60,61} \mathrm{~S}$. molle and S. paniculatum (and to a minor extent P. undulatum) possessed well-defined peaks in this region, and this may be responsible for the particles' tendency to agglomerate. 
All nanoparticle species contained peaks located in the regions of 1635-1545, 1430-1350, and $\sim 1000 \mathrm{~cm}^{-1}$ (Figure 3 ), which are representative of the stretching of the carboxylate group $(\mathrm{COO}-)$, bending of $\mathrm{O}-\mathrm{H}$ bonds from carboxylate groups, and $\mathrm{C}-\mathrm{O}$ stretching bonds, respectively. Peaks relating to $\mathrm{N}-\mathrm{H}$ bending are also found within the region of $1650-$ $1500 \mathrm{~cm}^{-1}$ and may be masked by the presence of the carboxylate signature. ${ }^{62-64}$

Nanoparticles from $P$. undulatum and $M$. azedarach showed an absence of strong signatures above $3000 \mathrm{~cm}^{-1}$ and possessed carboxylate groups, which have repulsive forces with other carboxylate groups. ${ }^{65}$ This may explain the formation of monodispersed nanoparticles generated within these samples.

Hexavalent Chromium Reduction. Within this study, an equal weight of nanoparticles $\left(5 \mathrm{mg} / \mathrm{mL} \mathrm{Cr}^{6+}\right.$ solution) was added to each treatment vessel as opposed to an equal volume of crude nanoparticle reaction solution. In this way, we were able to assess the efficiency of the nanoparticles on $\mathrm{Cr}^{6+}$ removal alone without the unreacted iron salt and unbound plant extracts interfering with the degradation kinetics. Mystrioti et al. ${ }^{66}$ showed that pomegranate and clove plant extracts alone could remove approximately $25 \% \mathrm{Cr}$ (VI) from solution over a 2-day period. This study also showed that clove extract possessed a low polyphenol content, however, it was still efficient at reducing $\operatorname{Cr}(\mathrm{VI})$. The authors mention that the type of polyphenols present within the plant may be a more important factor to focus on rather than the total polyphenol content of specific extracts.

In this current study, the plant extract of $P$. undulatum was the only plant extract, which had an impact on hexavalent chromium reduction with $100 \mu \mathrm{L}$ of extract resulting in approximately $35 \%$ removal of $\mathrm{Cr}(\mathrm{VI})$ in the same concentration and volumes as the nanoparticle $\mathrm{Cr}(\mathrm{VI})$ removal assays (data not shown). However, as capping of the particles only ranged from 3.3 to $5.4 \%$ of the total weight of the particles (determined by differences in weight following the removal of organic matter in a blast furnace at $500{ }^{\circ} \mathrm{C}$ for $12 \mathrm{~h}$ ), their influence is likely to have a negligible contribution to the overall $\mathrm{Cr}(\mathrm{VI})$ degradation within the nanoparticle treatment microcosms.

Although antioxidant concentration may show trends with increased reducing powers and hence in the formation of more concentrated nanoparticle solutions, when the ability of the resulting nanoparticles is assessed for $\mathrm{Cr}(\mathrm{VI})$ removal efficiency, they may not be the best performers.

This current study assessed the capacity of iron nanoparticles generated from plant extracts with different antioxidant profiles to remove $\mathrm{Cr}(\mathrm{VI})$. Plant-generated nanoparticles $(100 \mathrm{mg}$ ) with residual precursors removed were added to aqueous $\mathrm{Cr}(\mathrm{VI})$ solutions $(20 \mathrm{~mL}$ of $50 \mathrm{mg} / \mathrm{L}$ solutions). Results showed that $P$. undulatum- and $M$. azedarach-generated nanoparticles had significant and high $\mathrm{Cr}$ (VI) removal capacities with rates of 96.2 and $84.1 \%$, respectively, in over $9 \mathrm{~h}$ (Figure 4). Nanoparticles generated from $S$. molle, which showed the lowest antioxidant concentration and reducing power capacity had the lowest $\mathrm{Cr}$ (VI) removal efficiency (43.7\%). However, S. paniculatum, which possessed the highest antioxidant concentration and reducing power capacity was only able to achieve $58.7 \%$ $\mathrm{Cr}(\mathrm{VI})$ removal after $9 \mathrm{~h}$. As all nanoparticles were made up of mixed oxides, $\mathrm{Cr}(\mathrm{VI})$ removal dynamics was expected to be similar. As $\mathrm{Cr}(\mathrm{VI})$ removal after the first $15 \mathrm{~min}$ was slow and

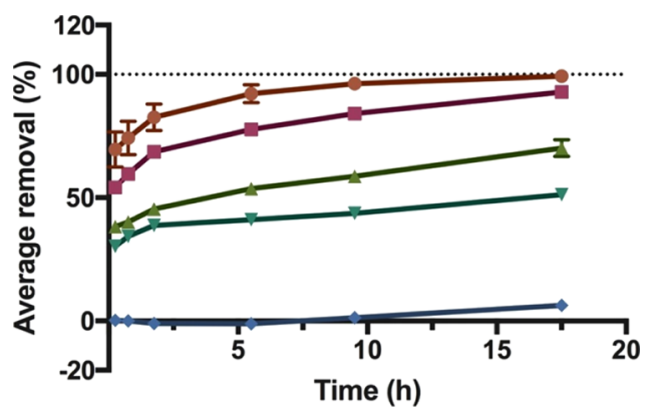

Figure 4. Plant-derived nanoparticles $(100 \mathrm{mg})$ efficiency for $\mathrm{Cr}^{6+}$ removal from aqueous solution $\left(20 \mathrm{~mL}\right.$ of $\left.50 \mathrm{mg} / \mathrm{L} \mathrm{Cr}^{6+}\right) ; P$. undulatum, $\square$ M. azedarach, $\triangle$ S. molle, $\nabla$ S. paniculatum, and $\bullet$ control.

steady, an absorption mechanism is suggested. This is supported by Jiang et al. ${ }^{67}$ who showed that absorption of $\mathrm{Cr}(\mathrm{VI})$ to maghemite nanoparticles was spontaneous and highly favorable.

Nanoparticle crystallinity, composition, surface bonds, and concentrations were similar (or the same), but their $\mathrm{Cr}$ (VI) removal capacities were different. This may be attributed to the size of the particles. It is widely documented that a decrease in the nanoparticle size greatly increases its surface area and in turn increases the available surface available for interactions to occur. $^{68-70}$ The nanoparticles that showed the highest $\mathrm{Cr}$ (VI) removal capacities had the smallest nanoparticle sizes, with most particles falling within the 5-15 nm size range. In addition, these nanoparticles were also quite monodispersed, further maximizing the particle surface area. Conversely, the two worst performing nanoparticle types possessed chainlike structures. Although the individual particles were nanometric in size, the linking of particles reduces their surface area, and as a result, they behave like millimetric-sized particles with reduced $\mathrm{Cr}(\mathrm{VI})$ removal capacity. It should also be mentioned that the type of phytochemicals capping the nanoparticles may also slow down the interactions between the pollutant and the particle. To enhance the nanoparticle capacity for removing $\mathrm{Cr}$ (VI) from wastewater, functionalization of nanoparticles may aid in both monodispersity and selective binding to $\mathrm{Cr}(\mathrm{VI})$. S. molle and S. paniculatum both showed agglomeration tendencies, and therefore, additions to the synthesis solution of species, which are able to counteract particleparticle attractions may be of benefit. Palma et al. in 2015 employed the use of meso-2,3-dimercaptosuccinic acid and oleic acid to generate monodispersed iron nanoparticles via a thermal decomposition route. ${ }^{71}$ In addition to the particle size, particle binding affinity may be enhanced by functionalizing nanoparticle-specific ligands. Elfeky et al. in 2017 modified iron oxide nanoparticles with cetyltrimethylammonium bromide (CTAB) and showed enhanced $\mathrm{Cr}(\mathrm{VI})$ binding selectivity and removal efficiencies. ${ }^{72}$ This treatment required low $\mathrm{pH}$ and the use of CTAB, which has been shown to be toxic to microorganisms. ${ }^{73}$ However, if nontoxic ligands can be applied to nanoparticles, this may aid in elevated remediation rates.

\section{CONCLUSIONS}

Reduction of iron salt precursors with different plant extracts can generate iron nanoparticles with different morphological features. However, the phytochemical fingerprints examined in this study were not comprehensive enough to link the compounds to morphology. All particles were composed of mixed iron oxide species and were amorphous in nature. Zero 
valent iron was not identified and is unlikely to be present in nanoparticles because of the lack of representative XRD and XPS peaks along with an absence of magnetism. Nanoparticles possessed $\mathrm{C}=\mathrm{C}, \mathrm{C}-\mathrm{O}, \mathrm{O}-\mathrm{C}=\mathrm{O}$, and $\mathrm{C}-\mathrm{OH}$ bonds on their surface, which was confirmed with XPS and FTIR analysis, indicating that they were capped with plant-based phytochemicals. Nanoparticles, which possessed strong $\mathrm{O}-\mathrm{H}$ bonds peaks in the FTIR analysis above $3000 \mathrm{~cm}^{-1}$, also showed agglomerated nanoparticles. The antioxidant concentration of plant extracts was linked with the reducing power capacity but not with optimum nanoparticle morphologies for chromium degradation. Plant extracts with the lowest and highest antioxidant concentrations showed the lowest $\mathrm{Cr}(\mathrm{VI})$ removal capacity for all nanoparticles tested. This was attributed to the nanoparticle-chained structures formed, which reduced the nanoparticle surface area and interaction with $\mathrm{Cr}(\mathrm{VI}) . P$. undulatum and $M$. azedarach possessed the highest $\mathrm{Cr}(\mathrm{VI})$ removal capacity of 96.2 and $84.1 \%$, respectively. Nanoparticles of these species were between 5 and $15 \mathrm{~nm}$ in size and were monodispersed. This research presents a green, costeffective, and efficient technology for the removal of $\mathrm{Cr}$ (VI) from aqueous solutions. Further research into the fractionation of plant extracts is required to determine the specific phytochemicals responsible for instilling specific nanoparticle traits. In addition, modification of nanoparticles using ligands with a strong affinity for specific pollutants is expected to deliver elevated remediation capacities. The immobilization of nanoparticles onto a solid support may be of interest for removing pollutants and nanoparticles from the environment following remediation.

\section{MATERIALS AND METHODOLOGY}

Dry Weight Determination. The water content of the plant leaves was determined by drying $10 \mathrm{~g}$ of fresh plant leaf biomass at $40{ }^{\circ} \mathrm{C}$ for $5 \mathrm{~h}$ or until no further weight change was apparent. Percentage moisture content was determined by the following equation

$$
\begin{aligned}
& \% \text { moisture content } \\
& =\text { (plant biomass following drying } \\
& \quad \text { initial weight of fresh biomass }) \times 100
\end{aligned}
$$

Preparation of Plant Extracts. Dried plant leaves of interest $(10 \mathrm{~g})$ were added to $100 \mathrm{~mL}$ of Milli-Q water and were put into a water bath at $80{ }^{\circ} \mathrm{C}$ for $1 \mathrm{~h}$ and then removed and allowed to cool at room temperature. The solution containing water-soluble phytochemicals was filtered through a $0.2 \mu \mathrm{m}$ filter and stored at $-20{ }^{\circ} \mathrm{C}$ until further use.

Phytochemical Analysis of Extracts. Trolox Equivalent Antioxidant Capacity (TEAC) Assay. The antioxidant capacity of the extract was determined using a modified method of that described by Stratil et al. ${ }^{74}$ and Re et al. ${ }^{75} \mathrm{ABTS}^{+}$cation stock solution was created by reacting $1: 1(\mathrm{v} / \mathrm{v})$ of $7 \mathrm{mM}$ ABTS (2,2' azino-bis(3-ethylbenzothiazoline-6-sulfonic acid) stock solution to $4.90 \mathrm{mM}$ potassium persulfate solution $(2.45 \mathrm{mM}$ final concentration). This solution was left to stand for $15 \mathrm{~h}$ at $25 \pm 2{ }^{\circ} \mathrm{C}$ in the dark to form the radical cation $\mathrm{ABTS}^{\bullet+}$.

To determine the TEAC, the $\mathrm{ABTS}^{+}$solution was diluted with phosphate-buffered saline (PBS, $\mathrm{pH}$ 7.4) to get an absorbance reading [optical density (OD)] between 1.0 and 1.5 at $734 \mathrm{~nm}$ when $200 \mu \mathrm{L}$ of the sample was measured on a 96-well plate reader (BMG POLARstarOmega).
A Trolox standard curve was created by making serial dilutions of an initial $1.5 \mathrm{mM}$ Trolox solution in PBS. Ten microliters of the Trolox solutions was added to $190 \mu \mathrm{L}$ of $\mathrm{ABTS}^{\bullet+}$ solution in a 96-well plate (COSTAR). Spectrophotometric measurements at $734 \mathrm{~nm}$ were taken exactly 6 min after initial mixing, and increased antioxidant concentration was determined by a decrease in the OD values.

The aforementioned procedure was repeated with $10 \mu \mathrm{L}$ of plant extract. Dilutions of plant extract (diluted in PBS, $\mathrm{pH}$ 7.4) were made if values fell outside the measurable range, and OD values were multiplied by the dilution factor. Findings are expressed as Trolox equivalents/g plant biomass [mM Trolox (equiv) $/ \mathrm{g}$ ]

PBS ( $\mathrm{pH}$ 7.4) and Trolox mixed with each corresponding plant extract in volumes used (without $\mathrm{ABTS}^{\bullet+}$ ) served as controls and standards.

Folin-Ciocalteu Assay. The phenolic content of plant extracts was determined by the Folin-Ciocalteu method, as outlined by Meda et al. ${ }^{76}$ and Moein et al. ${ }^{77}$ Briefly, the plant extract $(50 \mu \mathrm{L})$ was added to $450 \mu \mathrm{l}$ of Milli-Q water and filtered through a Whatman no. 1 filter paper. An aliquot (50 $\mu \mathrm{L}$ ) of this solution was then mixed with $250 \mu \mathrm{L}$ of $0.2 \mathrm{M}$ Folin-Ciocalteu reagent (Sigma-Aldrich Chemie, Steinheim, Germany) for $5 \mathrm{~min}$, and $200 \mu \mathrm{L}$ of $75 \mathrm{~g} / \mathrm{L}$ sodium carbonate $\left(\mathrm{Na}_{2} \mathrm{CO}_{3}\right)$ (Labosi, Paris, France) was added. After incubation at room temperature for $2 \mathrm{~h}$, the absorbance of $150 \mu \mathrm{L}$ from the reaction mixture was measured at $760 \mathrm{~nm}$ against methanol blank in a 96-well plate reader. Phenolic content is expressed as GA equivalents/g plant biomass [mg GA (equiv)/g].

The linear region of a standard curve, generated from the reaction of the above solution with GA $(0-0.50 \mathrm{mg} / \mathrm{mL})$, was used to determine the phenol content of plant extract samples (GA equivalents).

Reducing Power Assay. The $\mathrm{Fe}^{3+}$ reducing power (antioxidant capacity assay) of the extract was determined using the methods outlined by Berker et al. ${ }^{78}$ with modifications relating to the incubation method and the volumes of reagents. Briefly, $100 \mu \mathrm{L}$ pf Milli-Q $\mathrm{H}_{2} \mathrm{O}, 30 \mu \mathrm{L}$ of $0.20 \mathrm{M} \mathrm{HCl}, 30 \mu \mathrm{L}$ of ferricyanide solution (1\%), $10 \mu \mathrm{L}$ of sodium dodecyl sulfate (1\%), and $10 \mu \mathrm{L}$ of $\mathrm{FeCl}_{3} \cdot 6 \mathrm{H}_{2} \mathrm{O}$ $(0.2 \%)$ were combined to make a total of $180 \mu \mathrm{L}$ solution.

The plant extract or the standard to be tested was made up to $20 \mu \mathrm{L}$ with ethanol (96\%). The volume of the sample added to ethanol needed to be optimized to fit within measurable parameters, and this differed between samples tested.

Both the aforementioned final solutions were mixed together to make a $200 \mu \mathrm{L}$ solution, which was incubated at $50{ }^{\circ} \mathrm{C}$ within a thermocycler (Bio-Rad, T-100) for $20 \mathrm{~min}$ and then held at room temperature until further use. An aliquot (150 $\mu \mathrm{L}$ ) of the resulting sample was transferred to a 96-well plate (COSTAR), and the absorbance was measured at $700 \mathrm{~nm}$ $\left(A_{700}\right)$ against a reagent blank within $25 \mathrm{~min}$.

AA solution $(0.0-100.0 \mu \mathrm{g} / \mathrm{mL})$ was used as the standard. Increased absorbance of the reaction mixture indicated increased reducing power. Findings are expressed as L-AA equivalents/g plant biomass [mg AA (equiv)/g]. All measurements were conducted in triplicate in a 96 -well plate reader, BMG Labtech, Germany.

3,5-Dinitrosalicylic Acid (DNS) Assay. The reducing sugar content of plant extracts was determined using the DNS method, as outlined by King et al. ${ }^{79}$ Briefly, DNS working solution was prepared by combining $10 \mathrm{~g}$ of DNS with $403 \mathrm{~g}$ of $\mathrm{KNaC}_{4} \mathrm{H}_{4} \mathrm{O}_{6} \cdot 4 \mathrm{H}_{2} \mathrm{O}$ and then made up to $1 \mathrm{~L}$ in $0.4 \mathrm{M} \mathrm{NaOH}$ 
(heated at $50{ }^{\circ} \mathrm{C}$ till dissolved). The solution was then filtered through a $0.45 \mu \mathrm{m}$ filter.

Sixty microliters of glucose standard $(0.0-3.0 \mathrm{mg} / \mathrm{mL})$ prepared in $0.1 \mathrm{M}$ sodium acetate buffer $\mathrm{pH} 5.0$ or filtered plant extract was added to $120 \mu \mathrm{L}$ of DNS working solution in PCR tubes. PCR tubes were then placed into a PCR thermocycler (Bio-Rad, T-100), and the incubation cycle was set at $95{ }^{\circ} \mathrm{C}$ for $5 \mathrm{~min}$, cooling to $48^{\circ} \mathrm{C}$ for $1 \mathrm{~min}$, and holding at $20^{\circ} \mathrm{C}$.

Fifty microliters of the completed DNS reaction product was then added to $150 \mu \mathrm{L}$ of Milli-Q $\mathrm{H}_{2} \mathrm{O}$ in flat-bottom microplates (COSTAR), and the absorbance was measured at $540 \mathrm{~nm}$. Findings are expressed as glucose equivalents/g plant biomass $[\mathrm{mg}$ glucose (equiv)/g].

Ferrous Ion-Chelating Activity. The capacity of plant extracts to chelate $\mathrm{Fe}^{2+}$ ions was determined using the protocol described by Decker and Welch ${ }^{80}$ with some minor modifications. Briefly, to a flat-bottom 96-well plate (COSTAR), the following were added: $67.5 \mu \mathrm{L}$ of Milli-Q water, $50.0 \mu \mathrm{L}$ of the standard or plant extract, and $2.5 \mu \mathrm{L}$ of $\mathrm{FeCl}_{2}$. $4 \mathrm{H}_{2} \mathrm{O}(2 \mathrm{mM})$. The reaction was initiated by addition and thorough mixing of $5.0 \mu \mathrm{L}$ of ferrozine solution $(5 \mathrm{mM})$, and the reaction was allowed to develop in the dark for $10 \mathrm{~min}$. Absorbance values were measured using a 96-well plate reader (BMG POLARstarOmega, BMG Labtech, Germany) at 562 $\mathrm{nm}$. The linear region of a standard curve, generated from the reaction of the above solution with EDTA $(0-250 \mathrm{mg} / \mathrm{mL})$ was used to determine the metal chelation capacity of the plant extract samples. Results are expressed as EDTA equivalents/g plant biomass [mg EDTA (equiv)/g]

Iron Nanoparticle Synthesis. Preparation of Iron Nanoparticles. The plant extract was mixed in a beaker at top speed using a magnetic stirrer, and $0.1 \mathrm{M} \mathrm{FeCl}_{3} \cdot 6 \mathrm{H}_{2} \mathrm{O}$ solution was slowly introduced using a peristaltic pump with a flow rate of $2 \mathrm{~mL} / \mathrm{min}$, ensuring a $2: 1$ ratio $\mathrm{v} / \mathrm{v}$ of plant extract to $\mathrm{FeCl}_{3} \cdot 6 \mathrm{H}_{2} \mathrm{O}$, respectively. The color of the solution changed to black indicating the synthesis of nanoparticles. The resulting solution was centrifuged at $14000 \mathrm{~g}$ for $30 \mathrm{~min}$ within Amicon Ultra-0.5 Centrifugal Filter Devices with $10 \mathrm{kDa}$ cutoff; the flowthrough was discarded and the nanoparticles pelleted on the filter were resuspended in Milli- $\mathrm{Q}$ water, frozen to $-80^{\circ} \mathrm{C}$, and lyophilized.

Characterization of Plant-Generated Nanoparticles. Transmission Electron Microscopy (TEM). TEM characterization was undertaken for nanoparticles prior to the dye degradation reaction. Plant extract-generated nanoparticle samples were prepared by drop-coating the samples on a carbon-coated copper grid. The grid was left to dry overnight in a dust-free environment, and the morphological characteristics of iron nanoparticles were analyzed with a JEOL1010 TEM operated at $100 \mathrm{kV}$ (Thermoemission cathode).

FTIR Spectroscopy. FTIR spectroscopy spectra of freezedried plant extracts, plant extract-generated iron nanoparticles, and plant-generated nanoparticles with organic material burnt off at $500{ }^{\circ} \mathrm{C}$ for $10 \mathrm{~h}$ in a muffle furnace were determined by a Fourier transform infrared spectroscope (PerkinElmer Frontier). Nanoparticles were freeze-dried, washed in Milli-Q water, and centrifuged at $14000 \mathrm{~g}$, and the nanoparticles were retained. Nanoparticles were dried at room temperature before being processed by a spectroscope. An average of 18 scans was collected for each measurement with a resolution of $0.5 \mathrm{~cm}^{-1}$ in the range of $4000-400 \mathrm{~cm}^{-1}$.
$X R D$. To determine the crystalline phases of plant-generated nanoparticle, XRD analysis was conducted using a Bruker AXS D8 Discover diffraction instrument equipped with a $\mathrm{Cu} \mathrm{K} \alpha$ radiation source (wavelength $0.1542 \mathrm{~nm}$ ) operating at $40 \mathrm{kV}$ and $35 \mathrm{~mA}$. All X-ray data were obtained in the $u-2 u$ lockedcouple mode over a $2 u$ interval of $10-60$. The identity of the diffraction peaks was assigned through auto-fitting in the instrument software (Bruker Evaluation).

XPS. Nanoparticle surface compositions were analyzed by XPS (Thermo K-Alpha XPS). The instrument was equipped with an $\mathrm{Al} \mathrm{K} \alpha \mathrm{X}$-ray radiation source with a photon energy of $1486.6 \mathrm{eV}$. All measurements were conducted at room temperature under ultrahigh vacuum $\left(10^{-8} \mathrm{~Pa}\right)$. The $\mathrm{C} 1 \mathrm{~s}, \mathrm{O}$ $1 \mathrm{~s}$, and $\mathrm{Fe} 2 \mathrm{p}$ core level spectra were recorded with an overall resolution of $0.1 \mathrm{eV}$. The spectra were handled with Avantage 4.88 Surface Chemical Analysis Software, Thermo Scientific.

Hexavalent Chromium Removal. Aqueous solutions of $\mathrm{Cr}^{6+}(20 \mathrm{~mL}$ of $50 \mathrm{mg} / \mathrm{L})$ were prepared with $\mathrm{K}_{2} \mathrm{Cr}_{2} \mathrm{O}_{7}$ and buffered to $\mathrm{pH} 3.5$ in acetate buffer. The diphenylcarbazide (DPC) method was used to determine $\mathrm{Cr}^{6+}$ species in solution $^{81}$ with some minor modifications. To each $\mathrm{Cr}^{6+}$ solution, $130 \mu \mathrm{L}$ of DPC solution $(200 \mathrm{mg}$ of DPC/10 mL of acetone) was added. After $10 \mathrm{~min}$, time $0 \mathrm{OD}_{(540 \mathrm{~nm})}$ measurements were taken using a BMG POLARstarOmega using COSTAR flat-bottom 96-well plates. Following this, 100 $\mathrm{mg}$ of plant-generated nanoparticles was added to vessels and periodic $\mathrm{OD}_{(540 \mathrm{~nm})}$ measurements were taken for over $9 \mathrm{~h}$.

Hexavalent chromium removal efficiency (\%) was calculated as follows

Hexavalent chromium removal efficiency (\%)

$$
=100-\left(\left(C^{t} / C^{0}\right) \times 100\right)
$$

where $C^{0}$ is the $\mathrm{OD}_{(540 \mathrm{~nm})}$ of the hexavalent chromium/DPC complex at time 0 and $C^{t}$ is the $\mathrm{OD}_{(540 \mathrm{~nm})}$ of hexavalent chromium/DPC complex at time $t$.

Statistical Analysis. The concentrations of all bioactive components were compared within plant species and between plant species. Univariate ANOVA pairwise comparison coupled with Tukey and Duncan's multiple comparison post hoc tests were used to identify correlations at a 0.05 level.

\section{ASSOCIATED CONTENT}

\section{Supporting Information}

The Supporting Information is available free of charge on the ACS Publications website at DOI: 10.1021/acsomega.8b00410.

Enhanced magnification of nanoparticles and carbon, oxygen, and iron atomic composition from the XPS analysis (PDF)

\section{AUTHOR INFORMATION}

\section{Corresponding Author}

*E-mail: adam.truskewycz@rmit.edu.au (A.T.). ORCID

Adam Truskewycz: 0000-0003-1454-962X

Notes

The authors declare no competing financial interest.

\section{ACKNOWLEDGMENTS}

The authors would like to acknowledge the facilities and the scientific and technical assistance of the following: (1) 
Australian Microscopy \& Microanalysis Research Facility at the RMIT Microscopy \& Microanalysis Facility (RMIT University) and (2) Victorian X-Ray Structural Determination and Materials Characterisation Facility (RMIT University)

\section{REFERENCES}

(1) Guertin, J.; Jacobs, J. A.; Avakian, C. P. Chromium(VI) Handbook; CRC Press, 2016.

(2) Miyake, Y.; et al. Determination of hexavalent chromium concentration in industrial waste incinerator stack gas by using a modified ion chromatography with post-column derivatization method. J. Chromatogr. A 2017, 1502, 24-29.

(3) Markiewicz, B.; Komorowicz, I.; Barałkiewicz, D. Accurate quantification of total chromium and its speciation form $\mathrm{Cr}(\mathrm{VI})$ in water by ICP-DRC-IDMS and HPLC/ICP-DRC-IDMS. Talanta 2016, 152, 489-497.

(4) Elabbas, S.; et al. Removal of Cr(III) from chrome tanning wastewater by adsorption using two natural carbonaceous materials: Eggshell and powdered marble. J. Environ. Manage. 2016, 166, 589595.

(5) Jiang, B.; et al. Synergetic Transformations of Multiple Pollutants Driven by $\mathrm{Cr}(\mathrm{VI})$-Sulfite Reactions. Environ. Sci. Technol. 2015, 49, 12363-12371.

(6) Choppala, G.; Bolan, N.; Park, J. H. In Advances in Agronomy; Sparks, D. L., Ed.; Academic Press, 2013; Vol. 120, pp 129-172.

(7) Mishra, S.; Bharagava, R. N. Toxic and genotoxic effects of hexavalent chromium in environment and its bioremediation strategies. J. Environ. Sci. Health, Part C: Environ. Carcinog. Ecotoxicol. Rev. 2016, 34, 1-32.

(8) Owlad, M.; Aroua, M. K.; Daud, W. A. W.; Baroutian, S. Removal of Hexavalent Chromium-Contaminated Water and Wastewater: A Review. Water, Air, Soil Pollut. 2009, 200, 59-77.

(9) Sharma, S. K.; Petrusevski, B.; Amy, G. Chromium removal from water: a review. J. Water Supply: Res. Technol.-AQUA 2008, 57, $541-553$.

(10) Zhou, X.; Jing, G.; Lv, B.; Zhou, Z.; Zhu, R. Highly efficient removal of chromium(VI) by $\mathrm{Fe} / \mathrm{Ni}$ bimetallic nanoparticles in an ultrasound-assisted system. Chemosphere 2016, 160, 332-341.

(11) Albadarin, A. B.; et al. Experimental design and batch experiments for optimization of $\mathrm{Cr}(\mathrm{VI})$ removal from aqueous solutions by hydrous cerium oxide nanoparticles. Chem. Eng. Res. Des. 2014, 92, 1354-1362.

(12) Valle, J. P.; et al. Sorption of $\mathrm{Cr}(\mathrm{III})$ and $\mathrm{Cr}(\mathrm{VI})$ to $\mathrm{K} 2 \mathrm{Mn} 4 \mathrm{O}$ 9 nanomaterial a study of the effect of $\mathrm{pH}$, time, temperature and interferences. Microchem. J. 2017, 133, 614-621.

(13) Wang, T.; Lin, J.; Chen, Z.; Megharaj, M.; Naidu, R. Green synthesized iron nanoparticles by green tea and eucalyptus leaves extracts used for removal of nitrate in aqueous solution. J. Cleaner Prod. 2014, 83, 413-419.

(14) Luo, F.; Yang, D.; Chen, Z.; Megharaj, M.; Naidu, R. One-step green synthesis of bimetallic $\mathrm{Fe} / \mathrm{Pd}$ nanoparticles used to degrade Orange II. J. Hazard. Mater. 2016, 303, 145-153.

(15) Martínez-Cabanas, M.; López-García, M.; Barriada, J. L.; Herrero, R.; Sastre de Vicente, M. E. Green synthesis of iron oxide nanoparticles. Development of magnetic hybrid materials for efficient As(V) removal. Chem. Eng. J. 2016, 301, 83-91.

(16) Ahmmad, B.; et al. Green synthesis of mesoporous hematite $(\alpha$ Fe2O3) nanoparticles and their photocatalytic activity. Adv. Powder Technol. 2013, 24, 160-167.

(17) Sadgrove, N. J.; Jones, G. L. Chemical and biological characterisation of solvent extracts and essential oils from leaves and fruit of two Australian species of Pittosporum (Pittosporaceae) used in aboriginal medicinal practice. J. Ethnopharmacol. 2013, 145, 813-821.

(18) Bendaoud, H.; Romdhane, M.; Souchard, J. P.; Cazaux, S.; Bouajila, J. Chemical Composition and Anticancer and Antioxidant Activities of Schinus Molle L. and Schinus Terebinthifolius Raddi Berries Essential Oils. J. Food Sci. 2010, 75, C466-C472.
(19) Sukirtha, R.; et al. Cytotoxic effect of Green synthesized silver nanoparticles using Melia azedarach against in vitro HeLa cell lines and lymphoma mice model. Process Biochem. 2012, 47, 273-279.

(20) Wright, M. H.; Lee, C. J.; Pollock, C. E.; Greene, A. C.; Cock, I. E. Growth Inhibitory Activity of Selected High Antioxidant Australian Syzygium Species Against the Food Poisoning and Tissue Necrotic Pathogen Clostridium Perfringens. Pharmacogn. Commun. 2016, 6, 93.

(21) Mendes, M. D.; et al. ISSR molecular characterization and leaf volatiles analysis of Pittosporum undulatum Vent. naturalized in the Azores archipelago (Portugal). Ind. Crops Prod. 2011, 33, 710-719.

(22) Ramanibai, R.; Velayutham, K. Bioactive compound synthesis of Ag nanoparticles from leaves of Melia azedarach and its control for mosquito larvae. Res. Vet. Sci. 2015, 98, 82-88.

(23) Bendaoud, H.; Romdhane, M.; Souchard, J.-P.; Cazaux, S.; Bouajila, J. Chemical Composition and Anticancer and Antioxidant Activities of Schinus Molle L. and Schinus Terebinthifolius Raddi Berries Essential Oils. J. Food Sci. 2010, 75, C466.

(24) Vuong, Q. V.; et al. Physicochemical composition, antioxidant and anti-proliferative capacity of a lilly pilly (Syzygium paniculatum) extract. J. Herb. Med. 2014, 4, 134-140.

(25) Dorman, H. J. D.; Bachmayer, O.; Kosar, M.; Hiltunen, R. Antioxidant Properties of Aqueous Extracts from Selected Lamiaceae Species Grown in Turkey. J. Agric. Food Chem. 2004, 52, 762-770.

(26) Paul, K. G.; Frigo, T. B.; Groman, J. Y.; Groman, E. V. Synthesis of Ultrasmall Superparamagnetic Iron Oxides Using Reduced Polysaccharides. Bioconjugate Chem. 2004, 15, 394-401.

(27) Flora, S. J. S.; Pachauri, V. Chelation in Metal Intoxication. Int. J. Environ. Res. Public Health 2010, 7, 2745-2788.

(28) Satué-Gracia, M. T.; Heinonen, M.; Frankel, E. N. Anthocyanins as Antioxidants on Human Low-Density Lipoprotein and Lecithin-Liposome Systems. J. Agric. Food Chem. 1997, 45, 3362-3367.

(29) Netzel, M.; Netzel, G.; Tian, Q.; Schwartz, S.; Konczak, I. Native Australian fruits - a novel source of antioxidants for food. Innov. Food Sci. Emerg. Technol. 2007, 8, 339-346.

(30) Martínez-Cabanas, M.; López-García, M.; Barriada, J. L.; Herrero, R.; Sastre de Vicente, M. E. Green synthesis of iron oxide nanoparticles. Development of magnetic hybrid materials for efficient As(V) removal. Chem. Eng. J. 2016, 301, 83-91.

(31) Madhanraj, R.; Eyini, M.; Balaji, P. Antioxidant Assay of Gold and Silver Nanoparticles from Edible Basidiomycetes Mushroom Fungi. Free Radicals Antioxid. 2017, 7, 137.

(32) Rahimi-Nasrabadi, M.; Pourmortazavi, S. M.; Shandiz, S. A. S.; Ahmadi, F.; Batooli, H. Green synthesis of silver nanoparticles usingEucalyptus leucoxylonleaves extract and evaluating the antioxidant activities of extract. Nat. Prod. Res. 2014, 28, 1964-1969.

(33) Luque, R.; Varma, R. S.; Clark, J. H. Sustainable Preparation of Metal Nanoparticles: Methods and Applications; Royal Society of Chemistry, 2012.

(34) Shahwan, T.; et al. Green synthesis of iron nanoparticles and their application as a Fenton-like catalyst for the degradation of aqueous cationic and anionic dyes. Chem. Eng. J. 2011, 172, 258-266.

(35) Sulistyo, H.; Kurniawan, D.; Rujito, L. Biochemical and histopathological effects of green tea nanoparticles in ironized mouse model. Res. Pharm. Sci. 2017, 12, 99-106.

(36) Herlekar, M.; Barve, S.; Kumar, R. Plant-Mediated Green Synthesis of Iron Nanoparticles. J. Nanopart. 2014, 2014, 140614.

(37) Truskewycz, A.; Shukla, R.; Ball, A. S. Iron nanoparticles synthesized using green tea extracts for the fenton-like degradation of concentrated dye mixtures at elevated temperatures. J. Environ. Chem. Eng. 2016, 4, 4409-4417.

(38) Kuang, Y.; Wang, Q.; Chen, Z.; Megharaj, M.; Naidu, R. Heterogeneous Fenton-like oxidation of monochlorobenzene using green synthesis of iron nanoparticles. J. Colloid Interface Sci. 2013, 410, 67-73.

(39) Makarov, V. V.; et al. Biosynthesis of Stable Iron Oxide Nanoparticles in Aqueous Extracts of Hordeum vulgare and Rumex acetosa Plants. Langmuir 2014, 30, 5982-5988. 
(40) Njagi, E. C.; et al. Biosynthesis of Iron and Silver Nanoparticles at Room Temperature Using Aqueous Sorghum Bran Extracts. Langmuir 2011, 27, 264-271.

(41) Mohan Kumar, K.; Mandal, B. K.; Siva Kumar, K.; Sreedhara Reddy, P.; Sreedhar, B. Biobased green method to synthesise palladium and iron nanoparticles using Terminalia chebula aqueous extract. Spectrochim. Acta, Part A 2013, 102, 128-133.

(42) Phenrat, T.; Thongboot, T.; Lowry, G. V. Electromagnetic Induction of Zerovalent Iron (ZVI) Powder and Nanoscale Zerovalent Iron (NZVI) Particles Enhances Dechlorination of Trichloroethylene in Contaminated Groundwater and Soil: Proof of Concept. Environ. Sci. Technol. 2016, 50, 872-880.

(43) Carpenter, A. W.; Laughton, S. N.; Wiesner, M. R. Enhanced Biogas Production from Nanoscale Zero Valent Iron-Amended Anaerobic Bioreactors. Environ. Eng. Sci. 2015, 32, 647-655.

(44) Descostes, M.; Mercier, F.; Thromat, N.; Beaucaire, C.; Gautier-Soyer, M. Use of XPS in the determination of chemical environment and oxidation state of iron and sulfur samples: constitution of a data basis in binding energies for $\mathrm{Fe}$ and $\mathrm{S}$ reference compounds and applications to the evidence of surface species of an oxidized pyrite in a carbonate medium. Appl. Surf. Sci. 2000, 165, 288-302.

(45) Xian, H.; Peng, T.; Sun, H.; Wang, J. Preparation of graphene nanosheets from microcrystalline graphite by low-temperature exfoliated method and their supercapacitive behavior. J. Mater. Sci. 2015, 50, 4025-4033.

(46) Zhou, D.; Cheng, Q.-Y.; Han, B.-H. Solvothermal synthesis of homogeneous graphene dispersion with high concentration. Carbon 2011, 49, 3920-3927.

(47) Xia, X.; Lei, W.; Hao, Q.; Wang, W.; Wang, X. One-step synthesis of $\mathrm{CoMoO} 4 /$ graphene composites with enhanced electrochemical properties for supercapacitors. Electrochim. Acta 2013, 99, 253-261.

(48) Kalita, H.; Palaparthy, V. S.; Baghini, M. S.; Aslam, M. Graphene quantum dot soil moisture sensor. Sens. Actuators, B 2016, 233, 582-590.

(49) Gao, Y.; Wu, F.; Chen, H. Highly efficient Fe x Ni 1- x O y /CP electrode prepared via simple soaking and heating treatments for electrocatalytic water oxidation. J. Energy Chem. 2017, 26, 428-432.

(50) Han, J.; et al. Mechanism study on the sulfidation of $\mathrm{ZnO}$ with sulfur and iron oxide at high temperature. Sci. Rep. 2017, 7, 42536.

(51) Dreyer, A.; et al. Organically linked iron oxide nanoparticle supercrystals with exceptional isotropic mechanical properties. Nat. Mater. 2016, 15, 522-528.

(52) Mireles, L.-K.; Sacher, E.; Yahia, L. H.; Laurent, S.; Stanicki, D. Washing effect on superparamagnetic iron oxide nanoparticles. Data Brief 2016, 7, 1296-1301.

(53) Zhao, Y.; Dong, F.; Han, W.; Zhao, H.; Tang, Z. Promotion effect of oxygen-containing functional groups and Fe species on $\mathrm{Pd} @$ graphene for CO catalytic oxidation. New J. Chem. 2017, 41, 1205212060 .

(54) Palchoudhury, S.; Xu, Y.; Rushdi, A.; Holler, R. A.; Bao, Y. Controlled synthesis of iron oxide nanoplates and nanoflowers. Chem. Commun. 2012, 48, 10499-10501.

(55) Yamashita, T.; Hayes, P. Analysis of XPS spectra of Fe2+ and Fe3+ ions in oxide materials. Appl. Surf. Sci. 2008, 254, 2441-2449.

(56) Luo, F.; Yang, D.; Chen, Z.; Megharaj, M.; Naidu, R. The mechanism for degrading Orange II based on adsorption and reduction by ion-based nanoparticles synthesized by grape leaf extract. J. Hazard. Mater. 2015, 296, 37-45.

(57) Oliveira, R. N.; et al. FTIR analysis and quantification of phenols and flavonoids of five commercially available plants extracts used in wound healing. Matéria 2016, 21, 767-779.

(58) Mares-Briones, F.; Rosas, G. Structure and Stability of Gold Nanoparticles Synthesized Using Schinus molle L. Extract. J. Cluster Sci. 2017, 28, 1995-2003.

(59) Zhou, W.; Yoshino, M.; Kita, H.; Okamoto, K.-i. Carbon Molecular Sieve Membranes Derived from Phenolic Resin with a
Pendant Sulfonic Acid Group. Ind. Eng. Chem. Res. 2001, 40, 48014807.

(60) El Oudiani, A.; Msahli, S.; Sakli, F. In-depth study of agave fiber structure using Fourier transform infrared spectroscopy. Carbohydr. Polym. 2017, 164, 242-248.

(61) Attygalle, A. B.; Svatos, A.; Wilcox, C.; Voerman, S. Gas-Phase Infrared Spectroscopy for Determination of Double Bond Configuration of Monounsaturated Compounds. Anal. Chem. 1994, 66, $1696-1703$

(62) Mizuguchi, M.; Nara, M.; Kawano, K.; Nitta, K. FT-IR study of the Ca2+-binding to bovine $\alpha$-lactalbumin. FEBS Lett. 1997, 417, $153-156$.

(63) Kyomugasho, C.; Christiaens, S.; Shpigelman, A.; Van Loey, A. M.; Hendrickx, M. E. FT-IR spectroscopy, a reliable method for routine analysis of the degree of methylesterification of pectin in different fruit- and vegetable-based matrices. Food Chem. 2015, 176, $82-90$.

(64) Coates, J. Interpretation of Infrared Spectra, A Practical Approach. Encyclopedia of Analytical Chemistry. Meyers, R. A., Ed.; John Wiley \& Sons Ltd.: Chichester, 2000; pp 10815-10837.

(65) Canrinus, T. R.; Cerpentier, F. J. R.; Feringa, B. L.; Browne, W. R. Remarkable solvent isotope dependence on gelation strength in low molecular weight hydro-gelators. Chem. Commun. 2017, 53, $1719-1722$

(66) Mystrioti, C.; et al. Assessment of Polyphenol Coated Nano Zero Valent Iron for Hexavalent Chromium Removal from Contaminated Waters. Bull. Environ. Contam. Toxicol. 2015, 94, 302-307.

(67) Jiang, W.; et al. Chromium(VI) removal by maghemite nanoparticles. Chem. Eng. J. 2013, 222, 527-533.

(68) Wang, X.; Wang, P.; Ma, J.; Liu, H.; Ning, P. Synthesis, characterization, and reactivity of cellulose modified nano zero-valent iron for dye discoloration. Appl. Surf. Sci. 2015, 345, 57-66.

(69) Huang, L.; Weng, X.; Chen, Z.; Megharaj, M.; Naidu, R. Synthesis of iron-based nanoparticles using oolong tea extract for the degradation of malachite green. Spectrochim. Acta, Part A 2014, 117, 801-804.

(70) Chen, Z.-x.; Jin, X.-y.; Chen, Z.; Megharaj, M.; Naidu, R. Removal of methyl orange from aqueous solution using bentonitesupported nanoscale zero-valent iron. J. Colloid Interface Sci. 2011, 363, 601-607.

(71) Palma, S. I. C. J.; et al. Effects of phase transfer ligands on monodisperse iron oxide magnetic nanoparticles. J. Colloid Interface Sci. 2015, 437, 147-155.

(72) Elfeky, S. A.; Mahmoud, S. E.; Youssef, A. F. Applications of $\mathrm{CTAB}$ modified magnetic nanoparticles for removal of chromium (VI) from contaminated water. J. Adv. Res. 2017, 8, 435-443.

(73) Nakata, K.; Tsuchido, T.; Matsumura, Y. Antimicrobial cationic surfactant, cetyltrimethylammonium bromide, induces superoxide stress in Escherichia coli cells. J. Appl. Microbiol. 2010, 110, 568-579.

(74) Stratil, P.; Klejdus, B.; Kubáň, V. Determination of Total Content of Phenolic Compounds and Their Antioxidant Activity in VegetablesEvaluation of Spectrophotometric Methods. J. Agric. Food Chem. 2006, 54, 607-616.

(75) Re, R.; et al. Antioxidant activity applying an improved ABTS radical cation decolorization assay. Free Radicals Biol. Med. 1999, 26, $1231-1237$

(76) Meda, A.; Lamien, C. E.; Romito, M.; Millogo, J.; Nacoulma, O. G. Determination of the total phenolic, flavonoid and proline contents in Burkina Fasan honey, as well as their radical scavenging activity. Food Chem. 2005, 91, 571-577.

(77) Moein, M.; Moein, S.; Ahmadizadeh, S. Radical Scavenging and Reducing Power of Salvia mirzayanii Subfractions. Molecules 2008, 13, 2804.

(78) Berker, K. I.; Güçlü, K.; Tor, İ.; Apak, R. Comparative evaluation of $\mathrm{Fe}(\mathrm{III})$ reducing power-based antioxidant capacity assays in the presence of phenanthroline, batho-phenanthroline, tripyridyltriazine (FRAP), and ferricyanide reagents. Talanta 2007, $72,1157-1165$. 
(79) King, B. C.; Donnelly, M. K.; Bergstrom, G. C.; Walker, L. P.; Gibson, D. M. An optimized microplate assay system for quantitative evaluation of plant cell wall-degrading enzyme activity of fungal culture extracts. Biotechnol. Bioeng. 2009, 102, 1033-1044.

(80) Decker, E. A.; Welch, B. Role of ferritin as a lipid oxidation catalyst in muscle food. J. Agric. Food Chem. 1990, 38, 674-677.

(81) McCracken, K. E.; Angus, S. V.; Reynolds, K. A.; Yoon, J.-Y. Multimodal Imaging and Lighting Bias Correction for Improved $\mu$ PAD-based Water Quality Monitoring via Smartphones. Sci. Rep. 2016, 6, 27529. 